\title{
Section 5(b) of the Clayton Act: The Tolling Effect of Government Antitrust Actions on Unnamed Parties
}

\begin{abstract}
Big money makes substantial law out of what may have appeared to be small questions.

Matteoni, An Antitrust Argument
\end{abstract}

If a government action to enforce the antitrust laws results in a final judgment or decree to the effect that a defendant has violated those laws, section 5 of the Clayton Act ${ }^{1}$ allows the use of such a finding as prima facie evidence in a subsequent treble damage suit as to "all matters respecting which said judgment or decree would be an estoppel as between the parties thereto." 2 Section 5 also provides that the institution of a government antitrust action will toll the running of the statute of limitations $s^{3}$ as to any private antitrust cause of action "based in whole or in part on any matter complained of" in the government proceeding, during the pendency of the United States' action, and for one year thereafter. ${ }^{4}$ Michigan $v$. Morton Salt Co..$^{5}$ is the first case to hold

138 Stat. 731 (1914), as amended 69 Stat. 283 (1955), 15 U.S.C. $\& 16$ (1964).

215 U.S.C. $\$ 16(a)$ (1964). Section 5(a), in its entirety reads: "A final judgment or decree heretofore or hereafter rendered in any civil or criminal proceeding brought by or on behalf of the United States under the antitrust laws to the effect that a defendant has violated said laws shall be prima facie evidence against such defendant in any action or proceeding brought by any other party against such defendant under said laws or by the United States under Section I5a of this title, as to all matters respecting which said judgment or decree would be an estoppel as between the parties thereto: Provided, That this section shall not apply to consent judgments or decrees entered before any testimony has been taken or to judgments or decrees entered in actions under Section 15a of this title."

3 The statute of limitations applicable to all civil antitrust actions is four years. 69 Stat. 283, 15 U.S.C. $\S 15 b$ (1964).

415 U.S.C. $\$ 16(\mathrm{~b})$. The entire text of $\S 5(\mathrm{~b})$ is as follows: "Whenever any civil or criminal proceeding is instituted by the United States to prevent, restrain or punish violations of any of the antitrust laws, but not including an action under section 15a of this title, the running of the statute of limitations in respect of every private right of action arising under said laws and based in whole or in part on any matter complained of in said proceeding shall be suspended during the pendency thereof and for one year thereafter: Provided: however, That whenever the running of the statute of limitations in respect of a cause of action arising under section 15 of this title is suspended hereunder, and action to enforce such cause of action shall be forever barred unless commenced either within the period of suspension or within four years after the cause of action accrued."

The two provisions, formerly separate paragraphs of $\$ 5$, were denominated separate subsections by the 1955 amendments to the antitrust statutes, 69 Stat. 283 (1955). Most 
that a government action suspended the running of the statute with respect to parties joined as defendants in a treble damage action who had not been defendants in the action by the United States (herein "non-government defendants"). In this it stands alone against a considerable body of earlier precedent.

This comment will examine the Morton Salt approach, and the general theories of application of the tolling provision. After examining alternative statutory constructions, an attempt will be made to draw meaningful guidelines upon which the ambit of the tolling provision should be conditioned, considering both the practical positions of the treble damage plaintiff and the non-government defendant, and relevant antitrust policies.

\section{Section 5-Construction and Interpretation}

\section{A. Coextensiveness and Congressional Intent}

At the threshold of the investigation of the applicability of section 5 against non-government defendants lies the question of the relationship between sections $5(\mathrm{a})$ and $5(\mathrm{~b})$. One of the earliest and most influential cases to consider this problem was Momand $v$. Universal Film Exchange, ${ }^{6}$ the first instance of an attempted application of the tolling provisions against non-government defendants. ${ }^{7}$ The court there viewed

of the cases discussed herein were decided on the basis of $\S 5$ undivided into subsections (a) and (b). However, for the sake of convenience and clarity, the two provisions will be referred to as $\$ \S 5(\mathrm{a})$ and $5(\mathrm{~b})$, whether or not they were so considered in the case under discussion.

The 1955 amendments do not seem to be of any significance with regard to the instant problem. In rejecting the contention that Congress's failure to change the essential wording of the two sections indicated a legislative intent to leave prior case law undisturbed, the Eighth Circuit Court of Appeals wrote: "We find nothing in the language of the amendment itself or in its legislative history which evidences such an intention. . . . Clearly, Congress did not concern itself with the application of the tolling provision ... to those defendants who were not named in the government action." Hardy Salt Co. v. Illinois, Trade Reg. Rep. (1967 Trade Cas.) If 72104, at 83,962 (8th Cir. May 22, 1967), affirming Michigan v. Morton Salt Co., 259 F. Supp. 35 (D. Minn. 1966).

5259 F. Supp. 35 (D. Minn. 1966), aff'd sub nom. Hardy Salt Co. v. Illinois, Trade REG. REP. (1967 Trade Cas.) If 72104 (8th Cir. May 22, 1967) (a group of consolidated suits by agencies of various states against producers and distributors of rock salt used in maintaining state and municipal roads).

C 43 F. Supp. 996 (D. Mass. 1942) (Wyzanski, J.), aff'd, 172 F.2d 37 (1st Cir. 1948). The case involved a treble damage suit brought by the assignee of independent movie theater owners against the major film makers and distributors, alleging that the exhibitors were forced to enter into oppressive licensing agreements as a result of a conspiracy to eliminate competition in the production, distribution, and exhibition of motion pictures.

I It will be noted that the question of the applicability of $\S 5(b)$ to parties not joined in a prior government action arises because some participants in a conspiracy in restraint of trade may be spared prosecution by the Government. The Justice Department and the 
the tolling provision, section $5(\mathrm{~b})$, as merely a necessary adjunct to the prima facie evidence clause, section 5 (a). Thus, the tolling provision would operate against a defendant only if the judgment or decree that the Government might have won in the prior action could have served as evidence against that defendant under section 5(a). Since by the terms of section 5(a), a judgment or decree obtained by the Government can only be used against a defendant in the government litigation, the running of the statute of limitations with respect to non-government defendants would not be tolled by section $5(\mathrm{~b}) .^{8}$

The Momand court's conclusion ${ }^{9}$ that Congress had intended section 5 (b) as little more than an "enabling" provision for section 5(a), and that the two provisions were therefore coextensive ${ }^{10}$ was rejected by the Supreme Court in Minnesota Mining o Mfg. Co. v. New Jersey Wood Finishing Co. ${ }^{11}$ In Minnesota Mining the Court was faced with the problem of whether an FTC proceeding would toll the running of the statute under section 5(b). The Court assumed arguendo that an FTC decree would not be admissible under section $5(\mathrm{a})$, and thus came to grips with the question of the coextensiveness of the two provisions..$^{12}$

The Court concluded that, while in section 5(a) Congress was concerned with the "narrow issue" of the use of judgments obtained by the Government in treble damage actions, ${ }^{13}$ it had in mind a broader

FTC have limited funds and staff, KAYsen \&: Turner, ANTrTrust Policy 247 (1959) (hereinafter cited as KAYSEN \& TURNER), and in view of this, considerations of economy militate toward selective enforcement in many situations. It may be anticipated that prosecution of the key participants in the conspiratorial activities will generally serve to put an end to the conspiracy as a whole. Such a belief may lead the enforcement agency to minimize the number of parties and integrations attacked in one proceeding, in order to simplify the unavoidably complex matters of fact and economic analysis that will have to be proven. This may, be a particularly compelling consideration in the event of judicial proceedings, where the case will not be heard by a specialist tribunal. See Temporary National Economic Committee, 76th Cong., 3D Sess., Antitrust in Action 82-84 (Comm. Print 1940) (hereinafter cited as TNEC). Moreover, it seems likely, especially in the case of the FTC, that informal negotiations may result in some conspirators voluntarily abandoning the conspiracy, with proceedings being instituted only against the more recalcitrant offenders. See also note 55 infra.

8 Momand v. Universal Film Exchange, Inc., 43 F. Supp. 996, 1011 (D. Mass. 1942).

9 Concurred in by many courts since. See, e.g., Farmington Dowel Products Co. v. Forster Mfg. Co., 223 F. Supp. 967 (S.D. Me. 1963).

10 "This is clear from the juxtaposition of the two paragraphs which together constitute Section 5 of the Clayton Act." Momand v. Universal Film Exchange, Inc., 43 F. Supp. 996, 1012 (D. Mass. 1942).

11381 U.S. 311 (1965).

12 On both the question faced and the question avoided in Minnesta Mining, see Matteoni, An Antitrust Argument, 40 NOTRE DAME LAw. 158 (1965); Rockefeller, The Supreme Court and the Private Antitrust Plaintiff, 7 B.C. IND. \& CoM. L. REv. 279 (1966). 13381 U.S. at 317. 
purpose in connection with section $5(\mathrm{~b}) .{ }^{14}$ The opinion considered it "plain" that in enacting the tolling provision "congress meant to assist private litigants in utilizing any benefits they might cull from government antitrust actions." 15 The Court recognized that, in addition to benefits under section 5(a):

The Government's initial action may aid the private litigant in a number of other ways. The pleadings, transcripts of testimony, exhibits and documents are available to him in most instances. . . . Moreover, difficult questions of law may be tested and definitively resolved before the private litigant enters the fray. ${ }^{16}$

If, therefore, section $5(\mathrm{~b})$ is to fulfill its omnibus function, the Court reasoned, its operations should not be confined to cases in which the prima facie evidence provision is also applicable; benefits-pleadings, transcripts, exhibits, legal resolutions-flow as freely from proceedings which would not furnish benefits under section $5(\mathrm{a}) \cdot{ }^{17}$

The Court's conclusion that Congress had a broader purpose with respect to section $5(\mathrm{~b})$ than merely to provide a logical backstop for section $5(\mathrm{a})$ is, however, without affirmative support in the congressional history of the legislation. Indeed, not once is the tolling provision mentioned, except, and then only in passing, as a necessary complement to the prima facie evidence clause..$^{18}$ By the same token, however, the legislators expressed no intention contrary to, or out of harmony with, the Minnesota Mining interpretation of the statute. Rather, the Court's construction seems to be consistent with the broad congressional policy which it quite reasonably finds embodied in section $5(\mathrm{~b})$ : the desire to allow private litigants to take advantage of any benefits they might cull from government antitrust actions. ${ }^{19}$ In all likelihood, the legislators

14 Ibid.

15 Ibid.

16381 U.S. at 319.

17381 U.S. at 320 .

18 The Court even conceded: "The fact of the matter is that the records of the 1914 legislative proceedings reveals an almost complete absence of any discussion of the tolling problem." 381 U.S. at 320.

10 Section 5 was made a part of the Clayton Act apparently upon the request of President Wilson, who asked for a provision that would permit parties injured by antitrust violators to base recovery upon matter proved and adjudicated in suits brought by the Government, and would provide that "the statute of limitations . . . be suffered to run against such litigants only from the date of the conclusion of the Government's action." 51 CoNG. REc. 1964 (1914). The rationale behind the enactment was that aggrieved private parties should not have to retrace the costly route of proof that had been travelled by the Government: the "entire provision [was] intended to help persons of small means who are injured in their property or business by combinations or corporations violating the antitrust laws." H.R. REP. No. 627, 63d Cong., 2d Sess. 14 (1914). Thus, \& 5 represents 
simply did not think of benefits beyond those assured in section 5(a), but Minnesota Mining clearly represents a valid extrapolation of their desire to give substantial assistance to treble damage claimants.

\section{B. Supervening Requirements and Congressional Intent}

Some courts, beginning with Christensen v. Paramount Pictures, Inc., ${ }^{20}$ have based their opposition to the use of section $5(\mathrm{~b})$ against nongovernment defendants on a narrower ground than the coextensiveness argument urged in Momand and disapproved in Minnesota Mining. They have maintained that written into section $5(\mathrm{~b})$ is a supervening requirement that its application be limited to defendants who were named in the prior government action. The argument is that when using the words "any matter complained of," Congress had reference to the acts of the defendants of which the Government may have complained. ${ }^{21}$ In support of this construction, Christensen urged the following language of the 1914 House Report on section 5: "This section also provides that the statute of limitations shall be suspended in favor of private litigants who have sustained damage to their property or business by the wrongful acts of the defendant ...."22 The difficulty with this argument is that the Report's language does not define the limits of the statute's application. It could just as readily be inferred that the legislators had not considered the possibility of applying the tolling provision against non-government defendants, ${ }^{23}$ as that Congress consciously desired to limit the scope of section $5(\mathrm{~b})$. Furthermore, that Congress meant to make section $5(\mathrm{~b})$ a provision of broad application seems evi-

a congressional policy favoring treble damage suits, and a realization of the practical difficulties confronting a treble damage plaintiff. Cf. Dession, The Trial of Economic and Technological Issues of Fact, 58 YAle L.J. 1019 (1942); TNEG, at 83-84.

2095 F. Supp. 446 (D. Utah 1950), where a local movie theater owner sued major producers and distributors of motion pictures and a local exhibitor who had obtained unreasonable and preferential runs and clearances, relying on the judgment against the producers and distributors in United States v. Paramount Pictures, Inc., 334 U.S. 131 (1948), in which the local exhibitor had not been joined.

21 Court Degraw Theatre Corp. v. Loew's, Inc., 172 F. Supp. 198, 200 (E.D.N.Y. 1959); Electric Theatre Corp. v. Twentieth Century-Fox Film Corp., 113 F. Supp. 937, 945 (W.D. Mo. 1953); Christensen v. Paramount Pictures, Inc., 95 F. Supp. 446 (D. Utah 1950).

22 H.R. REP. No. 15657, 63 d Cong., 2d Sess. 14 (1914).

23 On the other hand, proponents of tolling against non-government defendants note that, while the focus of $\S 5(a)$ is on the defendant, on its face $\S 5(\mathrm{~b})$ "is not concerned with the defendants against whom the limitations period may be tolled," and therefore cannot be limited to use against government defendants. Michigan v. Morton Salt Co., $259 \mathrm{~F}$. Supp. 35, 55 (1966). In light of the legislative silence on the ambit of the tolling provision, this argument may be unconvincing, but it strengthens the view that Congress did not intend to restrict the use of the tolling provision to causes of action against defendants named by the Government. 
dent from the policy it embodies and from its potential utility in the context of antitrust legislation. ${ }^{24}$

\section{Severability Applied-The New Solution}

Leh v. General Petroleum Corp. ${ }^{25}$ represents an expansion of the Minnesota Mining principle. In Leh, the Supreme Court held the running of the statute tolled under section $5(\mathrm{~b})$ even though the treble damage claimant alleged conspiratorial activities that were slightly different from those averred in the initial government action; the case, however, did not involve non-government defendants. Taken together with Minnesota Mining, Leh largely discredited Christensen's reliance on the phrase "matter complained of" to preclude the broad application of section $5(\mathrm{~b})$. At the same time, the approach of such cases as Steiner v. 20th Century-Fox Film Corp. ${ }^{26}$ which required that "the same means ... to achieve the same objectives of the same conspiracies by the same defendants" ${ }^{\prime 27}$ must be alleged in both actions in order to activate the tolling provision was overruled. In Leh the Court found that the subject matter differences between the two actions did not foreclose application of section $5(\mathrm{~b})$ :

[E] ffect must be given to the broad terms of the statute itself"based in whole or in part on any matter complained of"(emphasis added) read in light of Congress's "belief that private antitrust litigation is one of the surest weapons for effective enforcement of the antitrust laws." ${ }^{28}$

And in this light, concern for the good faith of the private plaintiff in invoking the tolling provision (i.e., that his action was actually delayed in the expectation of help from the government litigation) must not lead to "a niggardly construction of the statutory language here in question." 29

Michigan v. Morton Salt Co ${ }^{30}$ dealt specifically with the problem of a limitations defense interposed by non-government defendants. ${ }^{31}$

24 See section IIB of this comment infra.

25382 U.S. 54 (1965).

26232 F.2d 190 (9th Cir. 1956). The facts were largely similar to those of Christensen v. Paramount Pictures, Inc., 95 F. Supp. 446 (D. Utah 1950), note 20 supra.

27232 F.2d at 196.

28382 U.S. at 59.

29 Ibid.

30259 F. Supp. 35 (D. Minn. 1966), aff'd sub nom. Hardy Salt Co. v. Illinois, Trade REg. REP. (1967 Trade Cas.) If 72104 (8th Cir. May 22, 1967).

31 The non-government defendants included some parties who had been named as coconspirators in the prior government action. The district court held that no distinction need be drawn between such parties and those who were not so designated. $259 \mathrm{~F}$. Supp. 35, 55 (D. Minn. 1966). The court of appeals did not decide the question, since the only 
Both Judge Larson's district court opinion and Judge Matthes' opinion for the circuit court of appeals indicated that the situation was controlled by the principles of Minnesota Mining and Leh. They reasoned that prior case law, whether grounded in notions of coextensiveness or supervening requirements, was effectively discredited by the Supreme Court's recent decisions; they rejected out of hand the suggestion that dissimilarity of parties defendant creates problems of special significance, or that it must be considered in a light different from any other sort of variance in the subject matter of the two complaints. Thus, the private and government complaints were found to be substantially identical and the private plaintiffs were allowed to invoke the tolling provision against all the defendants, including those not joined by the Government.

\section{Tolling Against the Non-Government DefendanT-Policies and Reaurties}

\section{A. The Effect of Tolling on Non-parties to the Government Action}

Two sorts of arguments may be advanced against allowing a government action to toll the running of the statute of limitations against nongovernment defendants. The first focuses on the detrimental effects on the non-government defendants; the second involves judgments about the effect of such a doctrine on the business community as a whole.

It may be argued that where a non-party to the government action is later joined in a treble damage suit that would be barred were it not for the operation of section $5(\mathrm{~b})$, his ability to present a defense will have been greatly impaired through loss of evidence and passage of time. ${ }^{32}$ However, it seems doubtful that a member of a business community that has been attacked in part by government action will be unaware of that action; if the given party was closely involved with the Government's defendants, whether culpably or not, it is suggested that some effort would be made by that party to determine the legal and practical

appellant had been a named coconspirator in the prior government action. Under the analyses suggested in section II of this comment infra, there seems no functional distinction between named coconspirators and other non-government defendants.

32 Some may argue that lack of notice of the suspension of the running of the limitations period may result in destruction of evidence which would otherwise have been kept. Of course, the culpable potential defendant may very well want to destroy incriminating records. Where those records are required by law to be kept for a certain length of time, and an action is brought against the party responsible for their maintenance at a date later than the period during which their maintenance is required-as is possible under a Morton Salt reading of $\S 5(\mathrm{~b})$, and possibly not otherwise-that party would avoid the permissible, unfavorable inference which would arise upon their nonproduction had the suit been brought during the period of time in which they were required to be kept. Cf. 9 WigMore, EvidENCE $\S 2524$ (3d ed. 1940), and authorities cited therein. 
effect of that action upon its position, and to take whatever steps may be deemed necessary by typically wary corporate managers to safeguard its interests. ${ }^{33}$

Furthermore, the lengthy nature of most antitrust litigation ${ }^{34}$ during which witnesses may die or move, and memories may fade, ${ }^{35}$ would. seem to work the same ravages upon the plaintiff's case. The plaintiff, in fact, may be more seriously disadvantaged, since he bears the burden of proof. Moreover, he must often rely heavily on the testimony of persons closest to the activities of the defendant, whose interests would presumably be adverse to those of the plaintiff, and whose propensity to forget incriminating facts may be aided by the passage of time.

The second argument against a Morton Salt construction of section $5(\mathrm{~b})$ is based on the proposition that the prolongation of the possibility of treble damage suits against a segment of the business community will have an inhibiting effect on the conduct of that community's business affairs; $^{36}$ this situation, moreover, may continue for a great period of

33 Absence of evidence is not solely a problem of non-government defendants. One can conceive of situations in which the availability of evidence would make it easier for a non-government defendant to defend against a subsequent private action than it would be for a party to the government suit. Since the private plaintiff can proceed against the government defendant even if they had no direct business dealings, see notes $42-44$ infra, and accompanying text, the government defendant, in such a case, may be hard pressed to refute allegations of injury stemming from transactions in which he was not directly involved. While the non-government defendant may have lost evidence concerning his dealings with the plaintiff, the government defendant never had any.

34 See KAYSEN \& TURNER 247. We may anticipate litigation that goes all the way to the Supreme Court lasting some eight to twelve years. United States v. Paramount Pictures, Inc., 334 U.S. 131 (1948), for example, lasted nine.

35 One of the prime objectives of statutes of limitation in general is to prevent claims from springing up long after the cause of action accrued, and surprising opposing parties when necessary evidence has been lost or depleted or the facts have become obscure from lapse of time or the defects of memory, death, or removal of witnesses. Chase Securities Corp. v. Donaldson, 325 U.S. 304 (1944); Order of Railway Express Telegraphers v. Railway Express Agency, 321 U.S. 342 (1943); Roland Electric Co. v. Black, 163 F.2d 417 (4th Cir. 1947).

36 Sales of businesses, or issues of stocks or bonds will be impaired by investors' fear of a possible treble damage action against the company. This insecurity, of course, will touch virtually all members of the segment of the business community attacked by the Government, since at the time of the government action it will not be possible to predict against whom treble damage actions will be brought, or in respect of which of these actions $\S 5(b)$ will operate to toll the running of the statute.

A simple expedient might be proposed for eliminating the problems associated with uncertainty as to whether or not a given party will be subject to the operation of the tolling provision. A provision might be added to $\$ 5(\mathrm{~b})$ to the effect that if a private party wished to rely upon a government action to toll the running of the statute in favor of a party not a defendant thereto, he would be required to so notify the potential defendant, before the expiration of the normal four year limitations period (subject to expansion by findings of fraudulent concealment or the like). The provision would have the virtue of delimiting the complete range of parties against whom treble damage suits 
time, the length of which is chiefly conditioned on the desire of the parties to the government action to contest.

Of course, this insecurity in the business community will result from a government action even if section $5(\mathrm{~b})$ is narrowly applied..$^{37}$ But the wisdom of allowing such a state of affairs to be extended for a virtually indeterminate period, to the detriment of what may be a large group of potential defendants who have no control over the period's length, must be subject to some doubts. These doubts are considerably allayed by the recognition that practical solutions to many of the problems of commercial insecurity have been devised, ${ }^{38}$ and by plaintiffs' and the general public's interests in broad application of section $5(\mathrm{~b})$.

\section{B. Public Policy and the Private Plaintiff}

The advantages which may accrue to a private plaintiff through the application of section $5(\mathrm{~b})$, as suggested by Minnesota Mining, ${ }^{39}$ include access to evidence, knowledge of the probability of success, and the pretesting of legal theories; the expense involved in bringing suit may be greatly reduced by the availability of such benefits.

It may be argued that, while a plaintiff might benefit from the government action if he chooses to sue non-government defendants, he will not, or at least need not, include such parties. It is true that in the large majority of cases, a treble damage claimant will not be in a position where he must sue non-government defendants or go without relief. Liability for acts done in furtherance of a conspiracy or combination in restraint of trade is joint and several, ${ }^{40}$ and full damages are therefore recoverable from any member of the conspiratorial group. ${ }^{41}$ For reasons which will

might arise after the expiration of the four year period, and it might help to insure against invocation of the tolling provision as an afterthought, solely to breathe new life into an otherwise stale claim.

On the other hand, because of the great ease with which such a provision could be abused, its operation might only serve to produce even greater chaos in the business community; blanket notices could be sent by potential plaintiffs to every member of the affected economic sector, crystalizing and amplifying the insecurity created by the government action. Furthermore, in any given case the sending of such a notice by one party to another with which it was doing business would probably result in strained relations between the two; multiplied many times, this might have deleterious effects on the flow of commerce.

37 Government accusation of illegal conduct suggests the possibility of related treble damage suits waiting in the wings, and these actions may be brought with or without benefits under $\$ 5$. See TNEC 80 .

38 One possibility is the sale of a business free of pre-existing liabilities. See Michigan v. Morton Salt Co., 259 F. Supp. 35, 55 (D. Minn. 1966).

39 See note 17 supra and accompanying text.

40 See, e.g., Sun Theatre Corp. v. RKO Radio Pictures, 213 F.2d 284, 293 (7th Gir. 1954); City of Atlanta v. Chattanooga Foundry \& Pipeworks, 127 Fed. 23 (6th Cir. 1903).

41 This is so whether or not the plaintiff has had direct dealings with the member of 
become apparent later, ${ }^{42}$ government defendants will probably always be jointly liable with non-government defendants against whom section 5 (b) is properly applied. Therefore, while in any given case the question of whether or not to apply section $5(\mathrm{~b})$ against a non-government defendant will be critical to the defendant-since the claim against it would otherwise be barred-it will probably not be so important for the private plaintiff. ${ }^{43}$

Nevertheless, a broad reading of section $5(\mathrm{~b})$, which would allow a private plaintiff to partake of the benefits of a government action and later apply them in a suit involving non-government defendants, seems especially desirable for two reasons. First, under the assumption that full enforcement ${ }^{44}$ of any remedial statute is desirable, it may be maintained that any firm or individual participating in antitrust violations should suffer legal sanctions. ${ }^{45}$ Accordingly, the treble damage action

the conspiracy that he sues, Karseal Corp. v. Richfield Oil Corp., 221 F.2d 358 (9th Cir. 1955), and despite the fact that the conspirator against whom recovery is sought was not a direct participant in, or received no direct benefit from, the particular acts complained of, if they were in furtherance of the conspiracy of which he was a part. Twentieth Century-Fox Film Corp. v. Goldwyn, 328 F.2d 190 (9th Cir. 1964).

42 See notes 57-63, 65 infra and accompanying text.

43 There are, of course, practical exceptions to this rule: it may be that some of the governmentally prosecuted defendants are not amenable to suit, either within the jurisdiction of the federal district court in the plaintiff's state, or generally, because of final dissolution; or the parties sued by the Government may now be insolvent, making a judgment against them relatively valueless. Although the probability of such circumstances seems rather limited, the possibility of their existence, in view of the remedial policy of antitrust legislation, certainly militates toward a broad application of $\S 5(\mathrm{~b})$.

Actually, the suggestion that government defendants may subsequently be found to be insolvent may not be quite as improbable as it seems, even in the face of the Government's customary practice of prosecuting chiefly the larger concerns, and the fact that such conspiracies generally involve fairly substantial members of oligopolistic industries. See KAYSEN \& TURNER 41. The pendency of a government action of necessity affects the commercial fortunes of a defendant thereto; investors certainly will hesitate to gamble on the enterprise, and others may shy away from doing business with it.

44 It must be borne in mind that treble damage actions were conceived as more than simple tort remedies; rather, the private antitrust action is considered an important mode of enforcement of the antitrust laws. Minnesota Mining \& $\mathrm{Mfg}$. Co. v. New Jersey Wood Finishing Co., 381 U.S. 311,318 (1965) ("Congress has expressed its belief that private antitrust litigation is one of the surest weapons for effective enforcement of the antitrust laws."); TNEC 82.

45 On the other hand, it has been argued that an expansive construction of $\$ 5(\mathrm{~b})$ would actually work to the detriment of government enforcement activities. Excluding consent decrees from the prima facie evidence provisions of $\$ 5(\mathrm{a})$ clearly represents a governmental desire to encourage prompt redress of antitrust violations through out of court settlements negotiated by violator and enforcement agency. Earlier cases held that when a defendant settles a government action, that action is no longer "pending" as to him, and the statute of limitations therefore begins to run again, see e.g., Sun Theatre Corp. v. RKO Radio Pictures, Inc., 213 F.2d 284 (7th Cir. 1954); Barnett v. Warner Bros. Pictures Distributing Corp., 112 F. Supp. 5 (D.C. 1953), and this doctrine clearly encour- 
would seem to be most effective as a means of filling gaps in the pattern of what must be selective prosecution ${ }^{46}$ by the federal government. ${ }^{47}$ The fact that the remedy of treble damages is penal or punitive in character not only supports this observation, but also suggests that Congress considered private retribution, as well as compensation and enforcement, when providing for such suits. ${ }^{48}$

ages early settlement of government suits. But in Morton Salt, the district court ruled that release by consent decree does not restart the running of the limitations period as to that defendant. 259 F. Supp. 35, 48-50 (D. Minn. 1966) (The point was not at issue on appeal, as all defendants to whom it might have been relevant had since settled out of the litigation.). The argument is that this holding takes away the government's "bargaining advantage" in negotiating consent decrees, and will therefore defeat the salutory policy of encouraging such settlements.

The district court decided the question of release by noting that Minnesota Mining and Leh emphasized the interest in promoting treble damage actions, and found this interest controlling. Judge Larson observed that while it is true that release of one defendant may end the possibility of $\S 5$ (a) benefits against that party, it does not end the continuing utility of the government litigation in making out a complete case against the released defendant; therefore, $\$ \S 5(a)$ and (b) are not coextensive, tolling must continue as long as the government action is pending as to anyone. (Judge Larson also noted that it would be a great burden on private plaintiff to have to bring an action against, or join each defendant in a subsisting action as he is released from the government suit, and then argue for continuances until evidentiary benefits are exhausted.) Such a holding is certainly doctrinally consistent with the rest of Morton Salt; moreover, to hold otherwise would create the anomaly of released government defendants being in a better position, with respect to the statute of limitations, than are parties who have never been joined in that litigation at all.

This analysis would suggest that there is an irrevocable tension between the interests of the private and public arms of antitrust enforcement; if this is so, it is submitted that the congressional policy embodied in $\S 5$ must control, and the private plaintiff must be served. However, in all probability, government enforcement practice will not really be hampered by a Morton Salt approach to $\S 5(\mathrm{~b})$. Release by consent decree means that a defendant will not be subject to the prima facie evidence provision of $\$ 5$ (a). The availability of $\S 5(a)$ benefits against a defendant would certainly seem to encourage private actions against that party, and is far more dangerous and damaging to a defendant than the subsidiary benefits which may accrue to a treble damage plaintiff from the trial of a government action. Thus, release from the provisions of $\S 5(\mathrm{a})$ is the most powerful lever for the Government in negotiating consent decrees, and the inability to release a party from further tolling would not seem to materially weaken the Government's position.

46 See note 7 supra.

47 "They [treble damage suits] may be the most effective way of policing the multitude of comparatively local and insignificant violations that will tend to escape the glance .of federal enforcement authorities or that, even if noticed, do not merit the expenditure of limited enforcement resources." KaYSEN \& TURNER 257. This would seem no less true even where overriding conspiratorial arrangements in the same segments of the economy have not "escaped the glance" of enforcement authorities. In this way, treble damage actions might serve to pull in the loose ends of conspiratorial activity attacked generally by the United States.

48 This observation is apparently endorsed by the Supreme Court: "It is clear that Congress intended to use private self-interest as a means of enforcement and to arm injured persons with private means to retribution when it gave to any injured party a 
Second, it should be observed that while the Government's selective enforcement may operate to bring to an end the entire scope of conspiratorial activities of any given integration attacked in part, ${ }^{49}$ facilitating private antitrust suits against participants not sued by the Government should increase the overall deterrent efficacy of the antitrust statutes. Since many kinds of unlawful agreements may not be effective without vertical integration of lower-level participants, ${ }^{50}$ a Morton Salt construction of section 5 (b) gives the statute greater deterrent effect by increasing the likelihood of an antitrust action against low level conspirators who may otherwise escape government prosecution.

\section{Structuring the Solution}

Given that facilitating treble damage suits against non-government defendants may at times outweigh the interests of such defendants and the business community in general in avoiding the consequences of depletion of evidence and commercial insecurity, there remains the problem of determining the proper scope of the tolling provisions.

Minnesota Mining and Leh made some progress toward a definition of the limit of variance between the government and private actions permissible under section 5(b). Minnesota Mining allowed the government action to toll the running of the statute in respect to the treble damage suit when the Court found that "both suits set up substantially the same claims." 51 Leh was somewhat more explicit, if not illuminating, on the requirement of substantial similarity: while the two complaints ${ }^{52}$ must bear a "real" relationship, a detailed duplication of

private cause of action in which his damages are to be made good threefold, with costs of suit and reasonable attorney's fees." Bruce's Juices v. American Can Co., 330 U.S. 743, $751-52$ (1947).

If retribution is a congressionally approved value in the antitrust setting, it must be desirable to allow the private plaintiff to include in his action those whose acts most directly or offensively harmed him.

49 See note 7 supra.

50 See generally Bork, The Rule of Reason and the Per Se Concept: Price Fixing and Market Division II, 75 YALE L.J. 373, 391-465 (1966).

51381 U.S. at 323.

52 Since tolling operates from the point of the institution of the government action, and a private litigant can only base his expectations of benefits on what may be ascertained about the Government's action at that time, Leh very properly notes that: "suspension of the running of the statute of limitations pending resolution of the government action may not be made to turn on whether the United States is successful in proving the allegations of its complaint." 382 U.S. at 65 . Inasmuch as the limitations issue is presented at the threshold of the private action, the Court continues: "The availability of $\S 5(b)$ to the private claimant may not be made dependent on his ability to prove his case, however fatal failure may prove to his hopes of success on the merits." Ibid. Thus, the decision as to tolling is dependent solely upon "a comparison of the two complaints on their face." Ibid. 
claims is not required..53 Of course, if the subject matter of the two suits is not largely the same, the government action will not really provide, or have promised to provide, the private plaintiff with the sort of benefits contemplated by the Court, and purported reliance on a government suit, the complaint in which does not bear a real relation to the private suitor's claim for relief, would be a mere sham. ${ }^{54}$

Morton Salt takes the substantial similarity requirement, or, in the words of that decision, the "test of substantial identity," as absolutely controlling in the case of all variances between the two actions-including variances in parties defendant. Both the district court and circuit court of appeals reasoned that the relevance of the government action to the treble damage claimant's case is the sole criterion for applying the tolling provision, and that since lack of government joinder may well be unrelated to involvement in the matters complained of in that action, ${ }^{55}$ the identity of parties defendant is merely another factor to be considered, along with allegations of time, place, and actions. When examining the substance of the two complaints, the parties factor has no independent or unique force in the equation. ${ }^{56}$

The thrust of the substantial similarity requirements developed in Minnesota Mining, Leh, and Morton Salt is that the congressional purpose of allowing a private plaintiff to cull benefits from government litigation is only served if section $5(\mathrm{~b})$ is invoked where reliance on the Government is not a fraud, and where it is at least possible that the private plaintiff delayed bringing suit in the expectation of real benefits from the initial proceeding.

There are many situations in which matters that the Government necessarily will prove under the allegations of its complaint will promise to be of substantial value to the private plaintiff in the development of a subsequent suit involving non-government defendants: for example, when the plaintiff has been injured by local activities in fullfillment of a nationwide conspiracy; or when the antitrust violations which caused injury to the plaintiff were initiated by conspirators otherwise vertically linked to the combination attacked by the United

53382 U.S. at 59.

54 Ibid.

55 See note 7 supra. The Supreme Court, if only by way of dictum, adverted to this in $L e h$, in a passage that both Morton Salt courts relied heavily upon: "In suits of this kind, the absence of complete identity of defendants may be explained on several grounds unrelated to the question of whether the private claimant's suit is based on matters of which the Government complained. ... [S]ome of the conspirators whose activities injured the private claimant may have been too low in the conspiracy to be selected as named defendants or co-conspirators in the Government's necessarily broader net." Leh v. General Petroleum Corp., 382 U.S. 54, 63-64 (1965).

56 See Michigan v. Morton Salt Co., 259 F. Supp. 35, 53-54 (D. Minn. 1966). 
States; ${ }^{57}$ or, in the simplest case, where the non-government defendants were co-conspirators with the parties named by the Government on the same horizontal level of integration. In instances such as these, the Government will prove agreements and acts in furtherance of those agreements. Proof of facts such as these is necessary to a private plaintiff's case..$^{58}$

On the other hand, the Government's proof may be relevant to the private plaintiff's case but not of substantial value. The private plaintiff may wish to use a crime proved by the Government as character evidence; ${ }^{59}$ he may wish to use acts proved by the Government for purposes of impeachment, ${ }^{60}$ or as evidence of bias; ${ }^{61}$ or he may hope to have points of law researched and general background information assembled concerning the techniques and economics of antitrust violations similar to his own case, as, for example, price fixing. ${ }^{62}$ It may also be that while government proof of its allegations might constitute weighty circumstantial evidence with respect to the plaintiff's claim, those proofs would not constitute a necessary ingredient of the plaintiff's case. ${ }^{63}$

57 As, for example, nationwide activities of distribution subsidiaries of conspiring manufacturing firms in a given industry. Something like the situation in United States v. Columbia Pictures Corp., 189 F. Supp. 153 (S.D.N.Y. 1960) may be envisioned here; in Columbia Pictures, however, only one distribution subsidiary, Screen Gems, Inc., was involved. It was wholly owned by one of the two defendant movie makers.

68 For example, just as proof that national film makers and distributors $A, B, C$, and $D$ conspired together on a nationwide scale would not entitle a movie theater operator to recover in a treble damage action, absent a showing of how that conspiracy affected business in his locality, so, presumably, proof that E, a local exhibitor, had obtained unreasonably favorable exhibition rights would not make out a complete claim for relief unless the plaintiff also showed that such exhibition rights were the fruits of a conspiracy in restraint of trade involving the producers and distributors of the films: A, B, C and D. Cf. Sun Theatre Corp. v. RKO Radio Pictures, 213 F.2d 284, 290 (7th Cir. 1954).

59 See, e.g., Mourikas v. Vardianos, 169 F.2d 53 (4th Cir. 1948).

60 See, e.g., Barnard v. Wabash Ry., 208 F.2d 489 (8th Cir. 1953).

o1 See, e.g., Terminal Transport Co. v. Foster, 164 F.2d 248 (5th Cir. 1929).

02 For example, government proof of a price fixing conspiracy among the five major producers of steel would certainly be instructive to a private plaintiff seeking to prove a similar conspiracy among the five major producers of copper.

63 This is perhaps the closest case of the lot. For example, consider the following hypothetical situation: The major American extractors of a given raw material have, by fixing prices at an abnormally high level, forced firms in a subordinate or derivative industry-producers or refiners of this raw material-into a position where they cannot sell at prices competitive with those of a foreign firm which both extracts and processes this material. (Previously, shipping costs had prevented the foreign company from competing in the American market.) However, the foreign firm can only supply a percentage of any one manufacturer's requirements of the processed material. To compel all the manufacturers to purchase the full amount of their requirements from them, the domestic processors agree among themselves to refuse to sell to any manufacturer who purchases from the foreign firm. (This boycott is effective since any given manufacturer is forced 
In either of the preceding sets of examples, the complaints in the government and private actions may present largely similar, or even identical, factual situations. But while tolling the statute against nongovernment defendants in the first class of cases is desirable, it is submitted that the benefits to treble damage claimants in the second class are not so great as to outweigh the detrimental effects upon non-government defendants and the business community in general; such a doctrine might well open a veritable Pandora's box, rendering the statute of limitations all but meaningless, and vitiating the policies it represents. It is suggested, then, that in testing the applicability of the tolling provision to non-government defendants in any given case, within the framework of the requirement of substantial similarity, ${ }^{64}$ the measure of the requisite relationship between the two complaints should be keyed to whether acts and agreements that the Government would prove under the allegations of its complaint will be necessary to the private plaintiff's recovery against the non-government defendants. ${ }^{65}$

Given this gloss on the formulation, and the assurances it provides, Morton Salt, and the approach it represents, must be approved. An excessively restrictive rule of application of section $5(\mathrm{~b})$ is not consonant with the policies underlying the enactment or the realities of

to choose between contracting his operations and buying at the higher price on the domestic American market.) Although the action of the American extractors may be said to be responsible for the processors' unlawful agreement, and proofs adduced by the United States in an action against the extractors would seem to be relevant circumstantial evidence in a manufacturer's action against the processors, the agreements and acts of the extractors are not really issues in the treble damage suit.

64 Although the substantial similarity formulation may seem indeterminate or difficult to apply, it must be noted that the calculation involved is much the same as is involved in determining, under the "same cause of action" criterion, the res judicata effect of one action on another, or whether a counterclaim is compulsory-questions encountered by the courts with great regularity. See generally, Developments in the Law-Res Judicata, 65 HARV. L. REV. 818 (1952). And the mechanics of the consideration of dissimilarities of parties defendant does not seem to pose any qualitatively different problems from those involved in the investigation of dissimilarities in any other sort of allegations in the two complaints-such as of time, place, or actions-which a court is required to make under the formulation.

65 It seems that the only situation in which proof of one firm's culpable behavior will be necessary to proof of another firm's culpability under the antitrust laws is where the two have acted in concert and the acts complained of were done in furtherance of an unlawful conspiracy or combination in restraint of trade. In this sort of relationship, as has been seen, liability is joint and several. This suggests that the guideline for applying the tolling provision against non-government defendants might be framed in terms of joint liability: the statute should only be tolled against a non-government defendant where, under the allegations of the complaints, the defendants in the government action, or some of them, would be liable for the private plaintiff's damages. It is questionable, however, that this formulation adds anything to the one suggested in the text. 
the antitrust world. At the same time, some functional limitation on the tolling provision's ambit is needed. Within the general framework of substantial similarity, the case of dissimilarities of parties defendant seems well governed by a limiting principle such as the one outlined above. 